\title{
GLACIOLOGICAL LITERATURE
}

THIs is a selected list of glaciological literature on the scientific study of snow and ice and of their effects on the earth; for the literature on polar expeditions, and also on the "applied" aspects of glaciology, such as snow ploughs, readers should consult the bibliographies in each issue of the Polar Record. For Russian material the system of transliteration used is that agreed by the U.S. Board on Geographic Names and the Permanent Committee on Geographical Names for British Official Use in 1947. Readers can greatly assist by sending reprints of their publications to the Society, or by informing Dr J. W. Glen of publications of glaciological interest. It should be noted that the Society does not necessarily hold copies of the items in this list, and also that the Society does not possess facilities for microfilming or photocopying.

\section{General glaciology}

Bull, C. [B. B.] Antarctic glaciology. Geotimes, Vol. 1 1, No. 4, 1966, p. 22-23. [Review of progress since beginning of I.G.Y.]

[Conferences.] Proceedings of the first international symposium on water desalination. Washington, D.C. October 3-9, 1965. Washington, D.C., U.S. Department of the Interior. Office of Saline Water, [ ${ }^{\mathrm{e}}{ }_{1967] .} 3$ vols.: $63^{2}$ p., 830 p., 792 p. \$3.25. [Full text of papers with summaries in French, Russian and Spanish. Includes the following papers: C. Jaccard, "Electrical properties of ice", Vol. 1, p. 224-39; V. A. Klyachko, "Research in the field of water desalination", Vol. I, p. $33^{\mathrm{I}-38}$; A. J. Barduhn, "The freezing process for water conversion in the United States", Vol. 2, p. 641-58; G. Bozza, G. Dassù [and] G. Giambelli, "On the freezing process", Vol. 2, p. 75 1-67; A. Peled, "Operation of the freeze desalination plant at Eilat, Israel", Vol. 3 , p. I-IO; J. W. Pike, "The direct contact controlled crystal desalination process", Vol. 3, p. I73-88; D. J. Sandell, Jr., and C. A. Johnson, "Direct freeze-wash separation process", Vol. 3, p. 625-50.]

[Glaciology: Arctic.] Glaciology in the Arctic, [by] Glaciology Panel, Committee on Polar Research[, Division of Physical Sciences, National Academy of Sciences-National Research Council]. Transactions. American Geophysical Union, Vol. 48, No. 2, 1967, p. 759-67. [Includes reports on sea ice (volume, condition and dynamics), glaciers, seasonal snow cover, frozen ground and Quaternary chronology.]

Jaworowski, Z. Temporal and geographical distribution of radium D (lead-210). Nature, Vol. 212, No. 5065, 1966, p. 886-89. [Concentration in snow and ice fluctuates and is greater in Arctic than temperate regions.]

McLeod, I. R. Glaciological observations in Enderby, Kemp, and Mac.Robertson [sic] Lands, Antarctica. ANARE Interim Reports. Series A (IV). Glaciology. Publication No. 9o, 1967, 48 p. [Snow and ice features, and topography of the ice sheet in $195^{8}$, 1959 and 1961 are described, also sea ice formation in $195^{8}$ and 1959 .]

Meier, M. F. Why study glaciers? In the context of water resources. Transactions. American Geophysical Union, Vol. 48, No. 2, 1967 , p. 798-802. [Major problems in an understanding of the hydrology of snow and ice.]

O'Leary, B. T. The presence of ice in the Venus atmosphere as inferred from a halo effect. Astrophysical Journal, Vol. 146, No. 3, i 966, p. 754-66. [Evidence for existence of ice crystals at top of clouds in Venus atmosphere.]

O'LeARY, B. T., and REA, D. G. Mars: influence of topography on formation of temporary bright patches. Science, Vol. ${ }_{155}$, No. 3760, 1967 , p. 31 $7^{-19}$. [Bright patches may be $\mathrm{CO}_{2}$ in depressions rather than ice on mountains.]

Oulianoff, N. De quelques termes employés dans la littérature glaciologique. Actes de la Société Helvétique des Sciences Naturelles, 1966, p. 137-39.

Ragle, R. H. Icefield Ranges Research Project, St. Elias Mountains, Yukon, 1966. Arctic, Vol. 20, No. I, I967, p. 49-53. [Study of Kaskawulsh Glacier medial moraine; morphological analysis of streams on a glacier; rock glacier studies; cation content of snow and ice in the area of the divide station; snow and ice sampling for analysis of ${ }^{210} \mathrm{~Pb}$; and Steele Glacier observations.]

Sekrra, J. Glacial geology and cryogeology of the Dronning Maud Land-East Antarctica (the Schirmacher Oasis-the Wohlthat Massif). Casopis pro Mineralogii a Geologii (Prague), [Vol.] 1 1, No. 2, 1966, p. 209 -16.

Tolstikov, Ye. I., ed. Atlas Antarktiki [Atlas of the Antarctic]. Moscow, Leningrad, Glavnoye Upravleniye Geodezii i Kartografii, 1966. xxiii, 225 p., maps. $60 \mathrm{~cm}$. [Distribution of natural phenomena over whole area, and by regions.]

Vendrov, S. L., and others. Grigoriy Aleksandrovich Avsyuk (k 6o-letno so dnya rozhdeniya) [Grigoriy Aleksandrovich Avsyuk (on his 6oth birthday)], [by] S. L. Vendrov [and 13 others]. Izvestiya Akademii Nauk SSSR. Seriya Geograficheskaya [.News of the Academy of Sciences of the U.S.S.R. Geographical Series], 1967, No. 2, p. $152-53$. [Tribute and biography.]

Wilhelm, F. Hydrologie, Glaziologie. Braunschweig, Georg Westermann Verlag, [ ${ }^{\mathrm{c}}$ I966]. 144 p. (Das Geographische Seminar.) [Includes sections on underground water, springs, rivers and seas, chemical properties of water, and glaciers (description, behaviour, and properties).]

\section{Glaciological instruments and methods}

Bauer, A. Utilisation de la photographie aérienne en glaciologie. (In Chevallier, R., ed. Photographie aérienne, panorama intertechnique. Paris, Gauthier-Villars, 1965, p. 65-68.) [Review of use of aerial photographs in

glaciology.]
Beaumont, R. T. Mt. Hood pressure pillow snow gage. Proceedings of the Western Snow Conference, 33 rd annual meeting, 1965 , p. 29-35. [Description of device for measuring water equivalent.]

Bertle, F. A. Snow compaction method for the analysis of runoff from rain on snow. Proceedings of the Western Snow Conference, 33 rd annual meeting, 1965, p. I I-18. [Method of computation described.] 
Bogorodskiy, V. V., and Fedorov, B. A. Radiolokatsiya lednikov [Radio echo-sounding of glaciers]. Zhurnal Tekhnicheskoy Fiziki [Journal of Technical Physics], Tom 37, Vyp. 4, 1967, p. 781-88. [Use during Soviet Antarctic Expedition near Mirny. English translation in Soviet Physics-Technical Physics, Vol. 12, No. 4, 1967 , p. $\left.5^{6} \mathrm{I}-66.\right]$

Bonneval, M. Mesure de la direction et de la vitesse d'écoulement d'un glacier par photogrammetrie. (In Chevallier, R., ed. Photographie aérienne, panorama intertechnique. Paris, Gauthier-Villars, 1965, p. 69-72.) [Description of method of determining glacier velocity by aerial photogrammetry.]

Bugayev, Yu. G. Opyt rabot s radiodal'nomerami v Antarktide [Experience of operating pulsed sound rangefinder in Antarctica]. Geodeziya $i$ Kartografiya [Geodesy and Cartography], No. 4, 1966, p. 10-14. [Use of this instrument under extreme conditions without loss of accuracy.]

Clough, J. W., and Bentrey, C. R. Electromagnetic sounding of glacial and shelf ice. Antarctic Journal of the U.S., Vol. 2, No. 4, 1967, p. 119-20. [Soundings of ice thickness in five areas in Antarctica during the 1966-67 field season. Two complete systems were used.]

Crozaz, G., and others. Artificial radioactivity reference horizons in Greenland firn, by G. Crozaz, C. C. Langway, Jr., and E. Picciotto. Earth and Planetary Science Letters, Vol. I, No. I, I966, p. 42-48. [Object was to investigate total $\beta$-activity in firn layers and to determine whether artificial nuclide variations exist which could be used to measure snow accumulation rates.]

DAnsGaARD, W., and others. The $\mathrm{Si}^{32}$ fallout in Scandinavia: a new method for ice dating, by W. Dansgaard, H. B. Clausen and A. Aarkrog. Tellus, Vol. 18, Nos. 2-3, 1966, p. 187-91. [Measurements on snow and old glacier ice in Jotunheimen, Norway, in 1962 show ${ }^{32} \mathrm{Si}$ as usable element for dating ice up to $2 \mathrm{ooO}^{-3} 3$ ooo years old.]

Grant, L. O., and others. Application of radar to snow surveying, by L. O. Grant, J. D. Marwitz and C. W. Thompson. Proceedings of the Western Snow Conference, 33rd annual meeting, 1965, p. 42-48. [Discussion of methods of using radar to study falling snow.]

JACCARD, C. Four-point method for measuring the volume and surface conductivities of a thin sample. Zeitschrift für angewandte Mathematik und Physik, Vol. 17, Fasc. 6, 1966, p. 657-63. [Details of method suitable for application to ice.]

Lambert, G., and others. Possibilities of using lead 210 as an atmospheric tracer, by G. Lambert, B. Ardouin, M. Nezami and G. Polian. Tellus, Vol. 18, Nos. 2-3, 1966, p. 421-26. [Use to date seasonal layers in snow.]

Lorius, C., and others. Sur une méthode gravimétrique simplifiée de détermination de l'épaisseur de glace en bordure de l'Antarctique, [par] C. Lorius, G. Rouillon et F. Helly. Comptes Rendus Hebdomadaires des Séances de l'Académie des Sciences (Paris), Sér. B, Tom. 264, No. 3, 1967, p. 266-69. [Description of simple gravimetric method for determining ice thickness at edge of ice sheet and comparison of depths so found with depths found by drilling at Cap André Prudhomme, Terre Adélie.]

Merer, M. F., and others. Multispectral sensing tests at South Cascade Glacier, Washington, by M. F. Meier, R. H. Alexander and W. J. Campbell. Proceedings of the fourth symposium on remote sensing of environment ... 1966 . . University of Michigan (Ann Arbor, Willow Run Laboratories, Institute of Science and Technology, University of Michigan), 1966, p. 145-59. [Correlative meteorological and photometric measurements were made on the ground; detailed glaciological information was available from past studies.]

Penton, V. E., and Robertson, A. C. Experience with the pressure pillow as a snow measuring device. Water Resources Research, Vol. 3, No. 2, 1967 , p. 405-08. [Useful for seasonal measurements; unreliable for short time-period variations.]

Pettengill, D. Ice auger. U.S. Geological Survey. Water Supply Paper No. 1822, 1966, p. 53-54. [Description of powered auger suitable for drilling holes through river ice up to $0.5 \mathrm{~m}$ thick.]

RinKER, J. N., and others. Radio ice-sounding techniques, by J. N. Rinker, S. Evans and G. de Q. Robin. Proceedings of the fourth symposium on remote sensing of environment .. 1966 ... University of Michigan (Ann Arbor, Willow Run Laboratories, Institute of Science and Technology, University of Michigan), I 1966 , p. 793-80o. [Evaluation of two VHF-band radar systems for measuring ice thickness and contouring bedrock profile of ice-rock interface, Greenland ice sheet, 1964.]

Shannon, W. G. Electronic methods of snow surveying. Soil Conservation, Vol. 23, No. 5, 1966, p. 107-09. [Continuous recording of snowfall, air temperature and water equivalent.]

\section{PHYsics OF ICE}

Adamson, A. W. Surface of very cold ice is nonpolar. Chemical and Engineering News, Vol. 44, No. 18, 1966, p. 50. [Adsorption of $\mathrm{N}_{2}$ at $78^{\circ} \mathrm{K}$ implies ice is non-polar at surface.]

AL-NAIMY, B. S., and others. An electron spin resonance study of the radiolysis and the photolysis of frozen ammonia-water systems, by B. S. Al-Naimy, P. N. Moorthy and J. J. Weiss. Fournal of Physical Chemistry, Vol. 70, No. II, 1966, p. $3654-60$. [Identification of $\mathrm{NH}_{2}$ radical as formed by $\gamma$-irradiation. Study of its production.]

Arias, D., and others. Electrical properties of ice doped with $\mathrm{NH}_{3}$, [by] D. Arias, L. Levi and L. Lubart. Transactions of the Faraday Society, Vol. 62, No. 523, 1966, p. 1955-62. [Dielectric constant and conductivity as function of temperature and $\mathrm{NH}_{3}$ concentration.]

BarnaAl, D. E., and LowE, I. J. Experimental free-induction-decay shapes and theoretical second moments for hydrogen in hexagonal ice. Journal of Chemical Physics, Vol. 46, No. 12, 1967, p. 480o-09. [Good agreement with model of nuclear magnetic resonance line shape which assumes that high-frequency proton tunnelling does not take place along the hydrogen bonds.]

Berendsen, H. J. C. Water structure in biological systems. Federation Proceedings. Federation of American Societies for Experimental Biology, Vol. 25, No. 3, Pt. I, 1966, p. 97 $1-76$. [Discussion of structure of $\mathrm{H}_{2} \mathrm{O}$ in biomolecular systems. Includes suggestion about ice nucleating ability of many steroid hormones.] 
Blinc, R., and Hadžr, D. Deuteron quadrupole coupling and hydrogen bonding in crystals. Nature, Vol. 212, No. 5068, 1966, p. 1307-09. [Use of deuteron magnetic resonance to study hydrogen bonds in, among other things, ice.]

Bogorodskiy, V. V., and Kнокнlov, G. P. Akusticheskiye kharakteristiki l'da, nakhodyashchegosya pod staticheskim davleniyem [Acoustic characteristics of ice under a static pressure]. Akusticheskiy Zhurnal [Acoustical fournal], Tom 13 , Vyp. 1, 1967, p. 18-22. [Velocity of sound in columnar polycrystalline ice up to 500 bar. Main effect attributed to recrystallization of ice. English translation in Soviet Physics-Acoustics, Vol. 13, No. I, 1967 , p. 14-17.]

Brill, R., and TiPpe, A. Gitterparameter von Eis I bei tiefen Temperaturen. Acta Crystallographica, Vol. 23, No. 3, I967, p. 343-45. [Accurate determination of lattice parameters of hexagonal ice, $15^{\circ}-200^{\circ} \mathrm{K}$. English summary.]

Campbell, E. S., and others. Interpretation of the energy of hydrogen bonding; permanent multiple contribution to the energy of ice as a function of the arrangement of hydrogens, [by] E. S. Campbell, G. Gelertner, H. Heinen and V. R. G. Moorti. Journal of Chemical Physics, Vol. 46, No. 7, 1967, p. 2690-707. [Review of present knowledge of hydrogen bond and of hydrogen positions in ice and calculation of energy variation for different hydrogen arrangements.]

De Micheli, S. M. DE, and Licenblat, A. R. Ice whiskers grown in subsaturated atmospheres. Fournal of the Atmospheric Sciences, Vol. 24, No. 3, 1967, p. 312-15. [Appearance of whiskers during evaporation of ice crystals.]

Grant, N. H. The biological role of ice. Discovery, Vol. 27, No. 8, 1966, p. 26-30. [Implications of discovery that some biochemical reactions are faster in ice.]

Grant, N. H., and Alburn, H. E. Acceleration of enzyme reactions in ice. Nature, Vol. 212, No. 5058, r966, p. 194. [Reactions faster in ice at $-23^{\circ} \mathrm{C}$ than in water at $+1^{\circ} \mathrm{C}$.]

Gunter, T. E. Electron paramagnetic resonance studies of the radiolysis of $\mathrm{H}_{2} \mathrm{O}$ in the solid state. Fournal of Chemical Physics, Vol. 46, No. 10, 1967, p. $3818-29$. [Study of OH radical in ice after electron irradiation at $77^{\circ} \mathrm{K}$.]

Hall, P. G., and Tompkins, F. C. Dielectric relaxation in water adsorbed on ionic crystals. Fournal of the Chemical Society, Sect. A, 1966, No. I, p. 36-40. [Study of dielectric loss of $\mathrm{H}_{2} \mathrm{O}$ adsorbed on $\mathrm{CaF}_{2}, \mathrm{MgO}, \mathrm{KCl}$ and AgI. Discussion of extent to which adsorbed layers are ordered and ice-like.]

James, D. W. Solidification kinetics of ice determined by the thermal wave technique. (In Peiser, H. S., ed. Crystal growth. Proceedings of an international conference on crystal growth, Boston, 20-24 June 1966. Oxford, etc., Pergamon Press, [ $\left.{ }^{\mathrm{C}} \mathrm{I}_{967}\right]$, p. ${ }_{767-73 .)}$ [Application to ice of method of determining kinetics of freezing normal to basal plane.]

Jones, S. J. Softening of ice crystals by dissolved fluoride ions. Physics Letters, Vol. 25 A, No. 5, i 967 , p. 366-67. [At $c$. $-70^{\circ} \mathrm{C}$ small amounts of $\mathrm{HF}$ considerably reduce stress in constant strain-rate tests and increase the creep rate.]

KIKUCHI, K. On the positive electrification of snow crystals in the process of their melting (III).-(IV). Journal of the Meteorological Society of Japan, Ser. 2, Vol. 43, No. 6, i 965, p. 343-5o; p. 35 I-58. [(III): relation between bubble concentration in ice and + charge generation during melting confirmed experimentally. (IV): during melting of bubbly ice, droplets seen to burst from surface carried negative charge.]

KIм, D.-Y., and Schmidt, V. H. Semiclassical theory of proton transport in ice. Canadian Fournal of Physics, Vol. 45 , No. 4, 1967, p. $1507-16$. [Calculation of mobility of protons in ice which agrees well with electrical conductivity experiments.]

Koros, R. M., and others. The sticking probability of water on ice, [by] R. M. Koros, J. M. Deckers, R. P. Andreas and M. Boudart. Chemical Engineering Science, Vol. 21, No. 10, 1966, p. 941-50. [Beam of water vapour molecules impinges on ice target and number sticking found.]

Krausz, A. S., and others. Tubular ice crystals, by A. S. Krausz, B. Harron and G. G. Litvan. Nature, Vol. 215. No. 5098,1967 , p. $271-73$.

Kröger, F. A. The chemistry of imperfect crystals. Amsterdam, North-Holland Publishing Co., 1964. xvi, 1039 p. [Ch. 18, "Special cases of disorder", has section 18.2, p. $75^{\circ}-67$, devoted to ice.]

Levi, L., and KoBAyashi, T. Ice filaments grown in a gradient of vapour pressure. Fournal of the Meteorological Society of Japan, Ser. 2, Vol. 45, No. 4, I967, p. 315 $5^{-25}$. [Study of the filaments which form when ice crystals, nucleated on fine threads, grow upwards and sublimate underneath, leaving a filament between crystals and thread.]

Levi, L., and Milman, O. Freezing potential of electrolytic solutions. Fournal of the Atmospheric Sciences, Vol. 23, No. 2, 1966, p. 182-86. [Experimental study for $\mathrm{NH}_{3}$ and $\mathrm{NaCl}$ solutions.]

Lieb, E. H. Exact solution of the $F$ model of an antiferroelectric. Physical Review Letters, Vol. 18, No. 24, 1967 , p. 1046-48. [Exact solution of phase transition and electrical properties of antiferroelectric structure similar to that of ice.]

Lieb, E. H. Exact solution of the problem of the entropy of two-dimensional ice. Physical Review Letters, Vol. 18, No. 17,1967, p. 692-94. [Entropy of two-dimensional square lattice obeying Bernal-Fowler rules found to be $k \ln (4 / 3)^{3 / 2}$ per molecule.]

Lieb, E. H. Exact solution of the two-dimensional Slater KDP model of a ferroelectric. Physical Review Letters, Vol. 19, No. 3, 1967, p. 108-10. [Exact solution of phase transition and electrical properties of ferroelectric structure similar to that of ice.]

Lindenmeyer, C. S., and Chalmers, B. Growth rate of ice dendrites in aqueous solutions. Fournal of Chemical Physics, Vol. 45, No. 8, 1966, p. 2807-08. [Measurement of free and substrate growth rates as function of supercooling and solute concentration.] 
Lindenmeyer, C. S., and Chalmers, B. Morphology of ice dendrites. Fournal of Chemical Physics, Vol. 45, No. 8, 1966, p. 2804-06. [Direction of dendrites growing in supercooled pure water, aqueous solution and on substrates.]

Maybank, J., and Barthakur, N. N. The growth and destruction of ice filaments in an electric field. Nature, Vol. 216, No. 5110,1967 , p. 50-52. [Letter. Study of filament-like ice crystals growing near a freezing water drop and their modification by an electric field.]

MorachevskiY, B. G. Ob aktivnosti chastits AgJv kachestve l'doobrazuyushchikh yader [On the activity of AgI particles as ice generating nuclei]. Izvestiya Akademii Nauk SSSR. Fizika Atmosfery $i$ Okeana [News of the Academy of Sciences of the U.S.S.R. Physics of the Atmosphere and Ocean], Tom 3, No. 1, 1967, p. 105-07. [If the isotope ${ }^{151} \mathrm{I}$ is used in the $\mathrm{AgI}$ it does not act as nucleus. English translation in Izvestiya. Academy of Sciences, U.S.S.R. Atmospheric and Oceanic Physics, Vol. 3, No. 1, 1967, p. 59-6o.]

Parungo, F. P., and Lodge, J. P., jr. Amino acids as ice nucleators. Journal of the Atmospheric Sciences, Vol. 24, No. 3,1967, p. 274-77. [Difference between optically active and inactive forms. Thermodynamic explanation.]

Parungo, F. P., and Lodge, J. P., jr. Molecular structure and ice nucleation of some organics. Fournal of the Atmospheric Sciences, Vol. 22, No. 3, 1965, p. 309-13. [Nucleating ability found to vary with potential strength of hydrogen bond between hydroxyl or carboxyl group and $\mathrm{H}_{2} \mathrm{O}$ molecule.]

Pinatti, D., and Mascarenhas, S. Electrical currents produced during the solidification of water (Costa Ribeiro effect). Journal of Applied Physics, Vol. 38, No. 6, 1967, p. 2648-52. [Description of apparatus in which freezing or melting rate can be controlled and associated current measured. Results quoted. Importance for thunderstorm electricity discussed.]

Pruppacher, H. R. On the growth of ice in aqueous solutions contained in capillaries. Zeitschrift für Naturforschung, Bd. 22A, Ht. 6, I 967, p. 895-901. [Observations of variation of dendritic growth rate with various dissolved monovalent ions.]

Qureshi, M. M., and Maybank, J. Further tests on the ice nucleation potential of meteoritic material. Nature, Vol. 211 , No. 5048, 1966, p. 508-o9. [Laboratory tests.]

Ramseier, R. O. Self-diffusion of tritium in natural and synthetic ice monocrystals. Fournal of Applied Physics, Vol. 38, No. 6, 1967 , p. $2553^{-56}$. [Measurement both parallel and perpendicular to $c$-axis from $-2.5^{\circ}$ to $-35 \cdot 9^{\circ} \mathrm{C}$. Interpretation as due to vacancy diffusion of $\mathrm{H}_{2} \mathrm{O}$ molecules.]

Riehl, N. Protonic mobility and its importance for biological systems. Transactions of the New York Academy of Sciences, Ser. 2, Vol. 27, No. 7, 1965, p. 772-81. [Discussion of proton motion along hydrogen bonds, particularly in ice. Also published in Phillips, G. O., ed. Energy transfer in radiation processes. Chemical, physical and biological aspects. Proceedings of the international symposium held at Cardiff, January, 1965. Amsterdam, Elsevier, 1966, p. 95-104.]

Roedder, E. Metastable superheated ice in liquid-water inclusions under high negative pressure. Science, Vol. 155 , No. 3768 , 1967 , p. $144^{1} 3^{-1} 7$. [Retention of ice up to $+6.5^{\circ} \mathrm{C}$ in liquid inclusions in minerals with negative pressure of $c$. Iooo bar.]

Roulleau, M., and Poc, M.-M. Électrocongélation des brouillards surfondus. Comptes Rendus Hebdomadaires des Séances de l'Académie des Sciences (Paris), Sér. B, Tom. 264, No. 21, 1967, p. $1480-83$. [Strong electric field causes freezing of supercooled mist droplets.]

Shreve, R. L. Migration of air bubbles, vapor figures and brine pockets in ice under a temperature gradient. Journal of Geophysical Research, Vol. 72, No. 16, 1967, p. 4093-100. [Theory, and comparison with reported experiments.]

Soules, J. A. Improved sophomore experiment to measure latent heat of fusion. American Fournal of Physics, Vol. 35, No. I, 1967 , p. 23-26. [Two forms of teaching experiment to determine latent heat of fusion of ice.]

Starr, J. R., and Mason, B. J. The melting of small ice spheres and cones. Quarterly fournal of the Royal Meteorological Society, Vol. 92, No. 394, 1966, p. 500-09. [Times of complete melting in airstreams of controlled temperature, humidity and velocity measured and compared with theory.]

Sutherland, Bill. Exact solution of a two-dimensional model for hydrogen-bonded crystals. Physical Review Letters, Vol. 19, No. 3, 1967, p. 103-04. [Solution of two-dimensional ice lattice in electric field.]

Tippe, A. Zum Piezoeffekte bei Eis I. Naturwissenschaften, 54. Jahrg., Ht. 3, ig67, p. 68-69. [Explanation of effect observed by A. Deubner, R. Heise and K. Wenzel, ibid., 47. Jahrg., Ht. 24, i96o, p. 600-0i, as not due to piezoelectricity.]

Weissmann, M., and others. On the hydrogen bond in an ice-like structure, [by] M. Weissmann, L. Blum and N. V. Cohan. Chemical Physics Letters, Vol. I, No. 3, 1967, p. 95-98. [Comparison of various methods of calculating hydrogen-bond energy between water molecules in ice.]

Williamson, R. B., and Chalmers, B. Morphology of ice solidified in undercooled water. (In Peiser, H. S., ed. Crystal growth. Proceedings of an international conference on crystal growth, Boston, 20-24 June 1966. Oxford, etc. Pergamon Press, $\left[{ }^{\mathrm{C}} \mathrm{I} 967\right]$, p. 739-43.) [Study of shapes of crystals formed at different supercooling and explanation.]

Yosıda, Z. Kōri no kesshō no hyōmen kōzō. I. Kesshō teimen no kōzō, kōri no kesshō no heikōkei [Surface structure of ice crystals. I. Structure of basal surface, equilibrium form of ice crystals]. Teion-kagaku [Low Temperature Science], Ser. A, Vol. 24, 1966, p. I-18. [Theory of equilibrium form of ice surface. English extended summary p. I $4^{-18} 8$.]

Zhitnikov, R. A., and Kolesnikov, N. V. Teoreticheskoye rassmotreniye matrichnykh sdvigov rasshchepleniy sverkhtonkoy struktury dlya atomov $\mathrm{Cu}, \mathrm{Ag}$ i Au, stabilizirovannykh v polyarnoy matritse $\left(\mathrm{H}_{2} \mathrm{O}\right)$ [Theoretical analysis of the matrix shifts of the split hyperfine structure of $\mathrm{Cu}, \mathrm{Ag}$, and $\mathrm{Au}$ atoms stabilized in a polar matrix $\left(\mathrm{H}_{2} \mathrm{O}\right)$ ]. Fizika Tverdogo Tela [Physics of the Solid State], Tom 9, Vyp. 1, 1967, p. 162-66. [Results for $\mathrm{Ag}$ and $\mathrm{Au}$ in good agreement with theory. English translation in Soviet Physics-Solid State, Vol. 9, No. I, 1967 , p. $121-24$. 
Zimbrick, J., and Kevan, L. Evidence for trapped dielectrons in ice. Fournal of the American Chemical Society, Vol. 89 , No. Io, 1967 , p. $2483-84$. [Letter. After high $\gamma$-irradiation electron resonance studies suggest two electrons can be trapped in the same $\mathrm{OH}^{-}$vacancy.]

\section{LAND ice. Glaciers. Ice shelves}

Adamson, R. G., and Cavaney, R. J. Volcanic debris-layers near Mount Melbourne, northern Victoria Land, Antarctica. New Zealand fournal of Geology and Geophysics, Vol. 10, No. 2, 1967, p. 418-21. [Description of layers in Campbell Glacier.]

Bayrock, L. A. Catastrophic advance of the Steele Glacier, Yukon, Canada. Alberta University. Boreal Institute. Occasional Publication No. 3, 1967, 35 p. [Report of survey, 20-23 August 1966. Maximum rate of flow was $46 \mathrm{ft}(\mathrm{I} 4 \mathrm{~m})$ per $24 \mathrm{~h}$ mainly by slipping at the base. At the toe, most of the motion could be accounted for by shearing along the base.]

Behrendt, J. C., and others. Geophysical reconnaissance in the Pensacola Mountains, by J. C. Behrendt, J. R. Henderson and L. J. Meister. Antarctic Journal of the U.S., Vol. 1, No. 4, 1966, p. 125-26. [Helicopter survey made during ${ }_{1965}-66$ austral summer included seismic reflection, gravity and aeromagnetic studies.]

Bertzel, J. E., and Bentley, C. R. Geophysical investigations in Marie Byrd Land. Antarctic Journal of the U.S., Vol. 2, No. 4, 1967 , p. 95-97. [Measurements of ice thickness, required for reduction of gravity data as well as for glaciological purposes.]

Bowman, G. C. Directional characteristics of ionosonde interference patterns from the Filchner Ice Shelf. $A V C O$ Corporation, AVCO Space Systems Division, Wilmington, Mass., Contract NSF-C403, Antarctic Research and Data Analysis, Scientific Report 24, AVSSD-0224-66-CR, I966, 34 p. [Use of apparatus intended to study ionosphere to find depth of ice shelf and dielectric constant of its ice.]

Brecher, H. H. Measurements of ice-surface movement by aerial triangulation. Antarctic fournal of the U.S., Vol. 2, No. 4, 1967, p. 123. [Variation of accumulation along line of markers was strikingly similar during two time intervals.]

Browne-Cooper, P. J., and others. Probable local seismicity at Wilkes, Antarctica, [by] P. J. Browne-Cooper, G. R. Small and R. Whitworth. New Zealand Journal of Geology and Geophysics, Vol. 10, No. 2, 1967, p. $443-45$. [Includes seismic records attributed to "ice-quakes".]

Crozaz, G., and Langway, C. C., jr. Dating Greenland firn-ice cores with Pb-2 Io. Earth and Planetary Science Letters, Vol. I, No. 4, I966, p. 194-96. [Method applied to depth profile of North Greenland ice sheet.]

Einarsson, E. H. Sudurbrún Mýrdalsjökuls við Gvendarfell. Breytingar sioustu roo ár o. fl. Jökull, [Vol.] 3, Ár 16, ı 966, p. 216-18. [Variations of the southern margin of Mýrdalsjökull at Gvendarfell. Between about 1870 and about 1890 the glacier margin advanced, but from then until 1966 it was on the whole retreating.]

Einarsson, T. Physical aspects of sub-glacial eruptions. Fökull, [Vol.] 3, Ár 16, 1966, p. 167-74.

Evison, F. E. Note on the aseismicity of Antarctica. New Zealand Journal of Geology and Geophysics, Vol. 10, No. 2, 1967 , p. $479-83$. [Suggests that scarcity of earthquakes is dues to thickening of ice sheet.]

Gluck, S. Détermination du lit rocheux sous la Mer de Glace par séismique-réflexion. Comptes Rendus Hebdomadaires des Séances de l'Académie des Sciences (Paris), Sér. D, Tom. 264, No. 19, 1967, p. 2272-75. [Seismic study of bed of Mer de Glace, France.]

Goncharov, E. P. Hydrometeorological observatory on the Fedčenko glacier. WMO Bulletin, Vol. I6, No. I, 1967 , p. 20-23. [Early history of glacier and construction of observatory at side of glacier in r $93^{2}$, described. Brief outline of results of research.]

Gow, A. J. Antarctic glaciological studies. Antarctic Fournal of the U.S., Vol. 2, No. 4, 1967, p. 121-22. [Investigations of the composition, structure, and mass balance of the Koettlitz Glacier.]

Heine, A. J. The McMurdo Ice Shelf, Antarctica: a preliminary report. New Zealand fournal of Geology and Geophysics, Vol. 10, No. 2, 1967, p. 474-78. [Ice movement and strain, density profiles and accumulation rates.]

Holdsworth, G. Investigation of Meserve Glacier. Antarctic Journal of the U.S., Vol. 2, No. 4, 1967, p. 123-24. [Determining conditions of ice flow at base of glacier. Micrometeorological investigations were continued both on moraine and glacier surface.]

KazAnskiy, A. B. Temperaturnoye pole lednikov [Temperature field of glaciers]. Geofizicheskiy Byulleten' [Geophysical Bulletin], No. 1 7, 1966, p. 25-32. [Theoretical determination. Emphasis on temperature near bed.]

Kotryakov, V. M. Opyt podscheta zapasov vody akkumulirovannoy v gornykh lednikakh Sovetskogo Soyuza [An attempt to calculate the water supplies accumulated in mountain glaciers in the Soviet Union]. Izvestiya Akademii Nauk SSSR. Seriya Geograficheskaya [News of the Academy of Sciences of the U.S.S.R. Geographical Series], 1966, No. 3, p. $43-48$.

Lazarev, G. E., and others. Podlednyy rel'yef shel'fovogo lednika Shekltona po dannym geofizicheskikh issledovaniy [Subglacial relief of the Shackleton Ice Shelf from geophysical data], [by] G. E. Lazarev, P. A. Stroyev, S. A. Ushakov [and] A. I. Frolov. Izvestiya Akademii Nauk SSSR. Fizika Zemli [Neres of the Academy of Sciences of the U.S.S.R. Physics of the Earth], ${ }_{9} 6_{5}$, No. 9, p. 44-53. [Gravity, seismic, hydrological and echosounding data compared. English translation in Izvestiya. Academy of Sciences, U.S.S.R. Physics of the Solid Earth, 1965, No. 9 [pub. 1966], p. 607-12.]

Liestøl, O. Storbreen glacier in Jotunheimen, Norway. Norsk Polarinstitutt. Skrifter, Nr. 141, 1967, 63 p. [Review of work, I $949-65$, including accumulation, ablation, mass balance, and surface speed.]

Oettli, M. Un monde glaciaire sous l'équateur: le Ruwenzori. Les Alpes. Revue du Club Alpin Suisse, $43^{\mathrm{e}}$ An., $3^{\mathrm{e}}$ Trimestre, 1967 , p. $162-65$. [General description.]

Ostrem, G. A new glacier map of Erdalsbreen/Vesledalsbreen: a part of the Jostedalsbreen ice-cap. Oslo, Norges Vassdragsog Elektrisitetsvesen, Hydrologisk Avdeling, 1967. 2 p., map [1 : 20 00o]. [Copies available from Hydrologisk Avdeling, Vassdragsvesenet, Postboks 5091 Mj, Oslo 3, Norway.] 
Østrem, G., and others. Glacio-hydrology, discharge and sediment transport in the Decade Glacier area, Baffin Island, N.W.T., by G. Ostrem, C. W. Bridge and W. F. Rannie. Geografiska Annaler, Vol. 49A, Nos. 2-4, 1967 , p. 268-82. [Mass balance studies were initiated in 1965 ; the 1965 budget was slightly positive.]

Outcalt, S. I., and MacPhail, D. D. A survey of neoglaciation in the Front Range of Colorado. University of Colorado Studies. Series in Earth Sciences, No. 4, 1965, 124 p. [Investigations of glacier net budget and regional climatic variation reveal curious metabolic characteristics of Front Range glaciers.]

Risk, G. F., and Hochstein, M. P. Subsurface measurements on the McMurdo Ice Shelf, Antarctica. New Zealand Journal of Geology and Geophysics, Vol. 10, No. 2, 1967, p. 484-97. [Measurement of ice melting rate at bottom and of density and temperature profiles.]

Ritchie, W. Note on the retreat of Reintindbre glacier (Frostisen). Norsk Geografisk Tidsskrift, Bd. 21, Ht. 2, $1967-68$, [pub.] 1967 , p. 143-44. [Comparison of surveys of front in 1906, 1934 and 1963.$]$

Robin, G. DE Q. Surface topography of ice sheets. Nature, Vol. 215, No. 5105, 1967, p. 1029-32. [Refinement of theory of relation between surface slope and depth of flowing ice sheets.]

Sснутт, V. A study of ablation gradient. Geografiska Annaler, Vol. 49A, Nos. 2-4, r967, p. 327-32. [Observations show that there is no clear relation between ablation gradient and latitude but that the ablation gradient is strongly dependent upon the degree of continentality.]

Suyetova, I. A. The dimensions of Antarctica. Polar Record, Vol. 13, No. 84, 1966, p. 344-47. [Analysis of modern data on area, mean elevation of ice and rock, thickness and volume of ice sheet and ice budget.]

Thorarinsson, S. The age of the maximum postglacial advance of Hagafellsjökul eystri (a tephrochronological study). Fökull, [Vol.] 3, Ár ı6, I 966, p. 207-10. [Between A.D. 850 and goo, glacier smaller than or maximally as large as in 1929; about 1670 , glacier reached its 1939 position; 1708 , extension of the glacier the same as in 1929 or 1939 ; glacier is now stagnant or receding.]

Tronov, M. V. Ledniki $i$ klimat [Glaciers and climate]. Leningrad, Gidrometeorologicheskoye Izdatel'stvo [Hydrological and Meteorological Publishing House], 1966. 407 p. [Glacial climatic regions and interactions between glaciers and climate.]

VinogRadov, O. N., and others., ed. Rukovodstvo po sostavleniyu kataloga lednikov SSSR [Guide for compiling the catalogue of glaciers of the U.S.S.R.], [edited by] O. N. Vinogradov, A. N. Krenke [and] P. N. Oganovskiy. Leningrad, Gidrometeorologicheskoye Izdatel'stvo [Hydrological and Meteorological Publishing House], I966. I54 p. [Detailed instructions for compilation of major reference work.]

Vivian, R., and Mallon, R. Fiches des glaciers français. Le glacier d'Argentière. Revue de Géographie Alpine, Tom. 55, Fasc. 3, I967, p. 579-82.

Vivian, R., and Mallon, R. Fiches des glaciers français. Le glacier du Tour. Revue de Géographie Alpine, Tom. 55, Fasc. 3, 1967, p. $5^{8} 3^{-86}$

\section{ICebergs. SeA, River AND LAKe ICE}

Adams, W. P., and Shaw, J. B. Studies of ice cover on Knob Lake, New Québec. Cahiers de Géographie de Québec, ${ }_{1} \mathrm{I}^{\mathrm{e}}$ An., No. 2, 1967 , p. 88-96. [Systematic observations of lake ice cover in the vicinity of Schefferville, Quebec.]

Bell, R. A. I. Lake Miers, south Victoria Land, Antarctica. New Zealand Journal of Geology and Geophysics, Vol. io, No. 2,1967 , p. $540-56$. [Includes study of lake ice and ablation phenomena on its surface.]

Berdennikov, V. P. Fizicheskiye kharakteristiki l'da zatorov i zazhorov [Physical characteristics of the ice in ice jams and ice gorges]. Trudy Gosudarstvennogo Gidrologicheskogo Instituta [Transactions of the State Hydrological Institute], Vyp. 129, 1965, p. 19-43. [Studies on ice in two rivers, including mechanical tests. English translation in Soviet Hydrology. Selected Papers, 1965, No. 4, p. 384-402.]

Bogorodskiy, V. V., and Galkin, E. I. Issledovaniye vnutrennego treniya plastin l'da so sloyem pri izgibnykh kolebaniyakh [Investigation of the internal friction of ice slabs with a layer of snow during flexural vibrations]. Akusticheskiy Zhurnal [Acoustical Journal], Tom 12, Vyp. 4, 1966, p. 411-15. [Investigations on slabs frozen in a tank of water in the laboratory. English translation in Soviet Physics-Acoustics, Vol. 12, No. 4, 1967 , p. $360-63$.

Bradie, R. A. SLAR imagery for sea ice studies. Photogrammetric Engineering, Vol. 33, No. 7, 1967, p. 763-66. [Use of side-looking airborne radar for study of sea ice under bad weather conditions or darkness.]

Bradley, J., and Palmer, D. F. Ice-cored moraines and ice diapirs, Lake Miers, Victoria Land, Antarctica. New Zealand Fournal of Geology and Geophysics, Vol. 10, No. 2, 1967, p. 599-623. [Discussion of mechanism of formation of these "moraines" in the lake ice over this lake.]

Bukina, L. A. Raspredeleniye po razmeram kristallov vnutrivodnogo l'da v turbulentnom potoke [Size distribution of frazil ice crystals in turbulent flow]. Izvestiya Akademii Nauk SSSR. Fizika Atmosfery i Okeana [News of the Academy of Sciences of the U.S.S.R. Physics of the Atmosphere and Ocean], Tom 3, No. 1, 1967, p. 58-68. [Experimental determination. English translation in Izvestiya. Academy of Sciences, U.S.S.R. Atmospheric and Oceanic Physics, Vol. 3, No. I, I967, p. 31-36.]

BuynitskiY, V. KH. Nekotoryye zakonomernosti raspredeleniya i formirovaniya dreyfuyushchikh morskikh l'dov $\mathrm{v}$ Antarktike [Some laws on the distribution and formation of drifting sea ice in the Antarctic]. Trudy Sovetskoy Antarkticheskoy Ekspeditsii [Transactions of the Soviet Antarctic Expedition], Tom 44, 1965, p. 27-34. [Sea-ice limits and zones of differing ice conditions from Prinsesse Astrid Kyst to Shackleton Ice Shelf, I961-62.]

BuynitskiY, V. KH. O vliyanii diatomovykh vodorosley na stroyeniye i prochnost' morskikh l'dov [On the effect of diatoms on the strength of sea ice]. Trudy Sovetskoy Antarkticheskoy Ekspeditsii [Transactions of the Soviet Antartic Expedition], Tom 44, I965, p. 83-88. [Experiments on samples of shore ice.] 
Buynitskiy, V. Кн., and Dmitrash, Zh. A. Novey dannyye po fizike morskikh l'dov Antarktiki [New data on the physics of Antarctic sea ice]. Trudy Sovetskoy Antarkticheskoy Ekspeditsii [Transactions of the Soviet Antarctic Expedition], Tom 44, 1965, p. 44-82. [Brine content, density, strength and elastic modulus of sea ice.]

Groen, P. The waters of the sea. Princeton, N.J., London, etc., D. Van Nostrand and Co. Ltd., 1967. 328 p. (Chapter on "Ice in the seas" includes: icebergs, ice islands, ground ice, formation, thawing and gravity of sea ice, thickness of polar ice, the "Great Ice Barrier", and ice drift.)

Hunkins, K. Inertial oscillations of Fletcher's Ice Island (T-3). Journal of Geophysical Research, Vol. 72, No. 4, 1967 , p. $1165^{-74}$. [Circular motion interpreted as inertial oscillations due to change of wind stress.]

KAGAN, B. A. O vertikal'nom profile skorosti prilivnogo techeniya v more, pokrytom l'dom [On the vertical profile of the tidal current velocity in ice-covered sea]. Izvestiya Akademii Nauk SSSR. Fizika Atmosfery $i$ Okeana [News of the Academy of Sciences of the U.S.S.R. Physics of the Atmosphere and Ocean], Tom 3, No. I, I967, p. 69-77. [Equations for profile of tidal current velocity in ice-covered sea. English translation in Izvestiva. Academy of Sciences, U.S.S.R. Atmospheric and Oceanic Physics, Vol. 3, No. 1, 1967, p. 37-41.]

KAgAn, B. A. Trekhmernaya model' prilivnogo potoka v more, pokrytom l'dom [Three-dimensional model of tidal flow in ice-covered sea]. Izvestiya Akademii Nauk SSSR. Fizika Atmosfery i Okeana [News of the Academy of Sciences of the U.S.S.R. Physics of the Atmosphere and Ocean], Tom 3, No. 5, 1967, p. 526-36. [Equations set up and used to deduce charts of tidal characteristics in Sea of Okhotsk. English abstract.]

Kerr, A. D. On plates sealing an incompressible liquid. International fournal of Mechanical Sciences, Vol. 8, No. 4, 1966, p. 295-304. [Mathematical study of problem of bearing capacity of ice floes on which melt water has partially refrozen.]

Nikolayev, S. YE. Ledoissledovatel'skiye raboty [Ice research]. Trudy Sovetskoy Antarkticheskoy Ekspeditsii [Transactions of the Soviet Antarctic Expedition], Tom 51, 1967, p. 101-07. [Experiments on mechanical properties of floating ice carried out off Mirny, 1963.]

Ofuya, A. O., and Reynolds, A. J. Laboratory simulation of waves in an ice floe. Fournal of Geophysical Research, Vol. 72, No. 14, 1967 , p. $3567-83$. [Use of model with thin polyethylene sheets floating on water to simulate sea ice.]

Romanov, I. P. Raspredeleniye l'dov i aysbergov v pribrezhnykh vodakh Antarktidy v navigatsiyu 1964 g. [Distribution of ice and icebergs in the coastal waters of Antarctica during the navigation season of 1964 ]. Trudy Sovetskoy Antarkticheskoy Ekspeditsii [Transactions of the Soviet Antarctic Expedition], Tom 51, 1967, p. $184-89$. [Floating ice observed by Soviet parties, long. $10^{\circ}-100^{\circ} \mathrm{E}$.]

Stonehouse, B. Occurrence and effects of open water in McMurdo Sound, Antarctica, during winter and early spring. Polar Record, Vol. ${ }_{13}$, No. 87, 1967, p. 775-78.

Tsurikov, V. L. O formirovanii ionnogo sostava i solennosti morskogo l'da [On the formation of the ionic composition and salinity of sea ice]. Okeanologiya [Oceanography], Tom 5, Vyp. 3, i $96_{5}$, p. 463-72. [Results of experiments on freezing sea-water and $\mathrm{NaCl}$ solution.]

Wilson, J. Tuzo. Are the structures of the Caribbean and Scotia Arc regions analogous to ice rafting? Earth and Planetary Science Letters, Vol. 1, No. 5, 1966, p. 335-38. [Analogy between thrust structures in young sea ice and structure of island arcs.]

Yeskin, L. I. Ledovyye nablyudeniya [Ice observations]. Trudy Sovetskoy Antarkticheskoy Ekspeditsii [Transactions of the Soviet Antarctic Expedition], Tom 51, 1967, p. 92-100. [Sea ice observations off coast of Antarctica, long. $10^{\circ}-100^{\circ}$ E., $\left.1962-63.\right]$

Zakharov, V. F. Nekotoryye osobennosti raschetnogo dreyfa l'da v more Laptevykh [Some features of the calculated drift of ice in the Laptev Sea]. Problemy Arktiki $i$ Antarktiki [Problems of the Arctic and Antarctic], Vyp. 23, 1966, p. 45-46. [Mean drift calculated from air pressure pattern over many years.]

Zdanovich, V. G., and Sharikov, Yu. D. Nekotoryye voprosy opredeleniya dreyfa l'dov s primeneniyem aerofotos"yemki [Some problems in determining the drift of ice from aerial photographs]. Problemy Arktiki $i$ Antarktiki [Problems of the Arctic and Antarctic], Vyp. 21, 1965, p. 81-88. [Improved method suggested.]

\section{Glacial geology}

Brown, M. J. F., and others. A new radiocarbon date for Wales, by M. J. F. Brown, I. D. Ellis-Gruffydd, H. D. Foster, D. J. Unwin. Nature, Vol. 21 3, No. 5082, 1967, p. 1220-21. [Results in new views on southern limit of Würm ice in Irish Sea basin.]

Corbel, J. Zones hypoglaciaires et hyperglaciaires lors du maximum des inlandsis quaternaires arctiques. Comptes Rendus Hebdomadaires des Séances de l'Académie des Sciences (Paris), Sér. D, Tom. 263, No. 16, 1966. p. 1055-57. [Study of Arctic Quaternary ice sheets shows region of strong glacierization on one side and of arid, periglacial region on the other.]

DAнL, R. Senglaciala ackumulationsformer och glaciationsförhållanden i Narvik-Skjomenområdet, Norge. Norsk Geografisk Tidsskrift, Bd. 21, Ht. 3, 1967-68, [pub.] i 967, p. 157-241. [Late-glacial accumulation forms and glaciation in the Narvik-Skjomen district, Norway, are described and discussed.]

Dauvillier, A. Sur le rôle de l'activité solaire et des migrations polaires dans l'origine et l'évolution de la vie terrestre. Comptes Rendue Hebdomadaires des Séances de l'Académie des Sciences (Paris), Sér. B, Tom. 263, No. 10 , 1966, p. 66o-63. [Eocambrian glaciation due to low level of atmospheric oxygen; subsequent glaciations to reduction of solar activity.]

Denton, G. H., and Sturver, M. Neoglacial chronology, northeastern St. Elias Mountains, Canada. American Journal of Science, Vol. 264, No. 8, 1966, p. 577-99. [Donjek and Kaskawulsh Glaciers, from i2 500 B.P. to present.]

Derbyshire, E. Discussion on the glacial map of Tasmania. Australian fournal of Science, Vol. 29, No. 4, 1966, p. ${ }_{102-03}$. [Report of discussion during ANZAAS meeting in Hobart concerning new glacial map and problems of Tasmanian glaciation.] 
Einarsson, T. Late- and post-glacial rise in Iceland and sub-crustal viscosity. Jökull, [Vol.] 3, Ár 16, 1966, p. $157-66$. [Subcrustal viscosity for Iceland is one order of magnitude less than that for Scandinavia (Einarsson, 1953).]

Flinn, D. The ice front in the North Sea. Nature, Vol. 215, No. 5106, 1967, p. 1151-54. [Belt of deeps suggests that at last glacial maximum Norwegian ice did not cross North Sea.]

Gabert-Delay, J. Moraines, terrasses et glacis de versant du bassin de Laragne. Revue de Géographie Alpine, Tom. 55, Fasc. 3, 1967, p. 52 1-48. [Study of moraines and other geomorphological features of this region of southern France.]

Gage, M. Accordant and discordant glacial sequences. Geological Society of America. Special Papers, No. 84, I965, p. 393-414. [Contrast between accordant and discordant histories illustrates the "topographic" element in Flint's "solar-topographic" generalization of the causes of glaciations.]

Gage, M. The climate of New Zealand during cool phases of the Pleistocene. In Pleistocene and post-Pleistocene climatic variations in the Pacific area. Honolulu, Bishop Museum Press, 1966, p. 83-94. [Willett's (I950) estimate of $3500 \mathrm{ft}(\mathrm{I}$ o0o m) average lowering of snow line is still regarded as reasonable for the last glaciation, but may not be applicable to earlier glaciations.]

Grindley, G. W. The geomorphology of the Miller Range, Transantarctic Mountains, with notes on the glacial history and neotectonics of East Antarctica. New Zealand Journal of Geology and Geophysics, Vol. 10, No. 2, 1967 , p. $557-98$.

Heuberger, H. Gletschergeschichtliche Untersuchungen in den Zentralalpen zwischen Sellrain- und Ötztal. Innsbruck, Universitätsverlag Wagner, 1966. 127 p., map [in end-pocket]. (Wissenschaftliche Alpenvereinshefte, Ht. 2o.) [Analysis of glacial geological features and interpretation for this region of the Austrian Alps.]

Hoppe, G. Case studies of deglaciation patterns. Geografiska Annaler, Vol. 49A, Nos. 2-4, 1967, p. 204-1 2. [Describes two cases of rather complicated patterns of deglaciation and ice movements.]

Karser, K. Probleme und Ergebnisse der Quartärforschung in den Rocky Mountains (i.w.S.) und angrenzenden Gebieten. Zeitschrift für Geomorphologie, Neue Folge, Bd. 10, Ht. 3, 1966, p. 264-302. [Discussion of present and Pleistocene snow line in Rocky Mountains and climatic implications. French and English summaries.]

Krayner, N. P. S.S. Kutorga o drevnem oledenenii Al'p [S.S. Kutorga on the ancient glaciation of the Alps]. Izvestiya Akademii Nauk SSSR. Seriya Geograficheskaya [News of the Academy of Sciences of the U.S.S.R. Geographical Series], 1966, No. 6, p. 66-74. [Work of pioneer Russian investigator published 1840-58.]

Laverdière, C. Le vocabulaire de la géomorphologie glaciaire, III. Cahiers de Géographie de Québec, $1_{1}^{\mathrm{e}}$ An., No. 2 , I 967 , p. $102-07$.

Lewis, C. A. The Breconshire end-moraine. Nature, Vol. 212, No. 5070, 1966, p. 1559-61. [Discussion of limits of ice during last glaciation.]

McCulloch, D., and Hopkins, D. Evidence for an early Recent warm interval in northwestern Alaska. Geological Society of America. Bulletin, Vol. 77, No. 10, 1966, p. 1089-107. [Radiocarbon dating of warm period 10 ooo8 300 B.P.]

Mrtchell, G. F., and Orme, A. R. The Pleistocene deposits of the Isles of Scilly. Quarterly Journal of the Geological Society of London, Vol. 123, No. 489, Pt. 1, 1967, p. 59-92. [Existence of till and outwash gravel along the northern margin of the Scilly Isles. The sequence is compared with similar deposits in the south of England and Ireland.]

Mölder, K. Über die Entstehung des inneren Salpausselkä zwischen Jaala und Saimaa. Bulletin de la Commission Géologique de Finlande, Tom. 38, No. 222, 1966, p. 75-92. [Description of conditions which gave rise to this esker.]

Nichols, R. L. Geomorphology of Antarctica. (In Tedrow, J. C. F., ed. Antarctic soils and soil forming processes. Washington, D.C., American Geophysical Union, 1966, p. I-46. (Antarctic Research Series, Vol. 8.)) [Includes glacial and periglacial geomorphology.]

OEN ING Soen. Geomorphological observations on Sermersôq. A contribution to the geomorphology of S. Greenland. Meddelelser om Grenland, Bd. I 79, Nr. 5, I965, 41 p. [Four erosion surfaces recognized and related to three cycles of erosion interrupted by two glacial stages.]

Peacock, J. D. West Highland morainic features aligned in the direction of ice flow. Scottish Journal of Geology, Vol. 3, Pt. 2, 1967, p. 372-73. [Surface features of glacial deposit aligned by overriding ice.]

Peterson, J. A. Glaciation of the Frenchman's Cap, National Park. Papers and Proceedings of the Royal Society of Tasmania, Vol. 100, I966, p. I 1 7-29. [Study of glacial landforms suggests an independent system of cirque and valley glaciers during the last Pleistocene glaciation of this part of Tasmania.]

Portmann, J.-P. Recherches géo-glaciologiques. Les Alpes, $43^{\mathrm{e}}$ An., $3^{\mathrm{e}}$ Trimestre, i 967 , p. I90-91. [Necessity of recording geographical features, e.g. nature of rocks incorporated in glacier and periglacial features.]

Shackleton, N. Oxygen isotope analyses and Pleistocene temperatures re-assessed. Nature, Vol. 215, No. 5096, $1967, \mathrm{p}, \mathrm{I}^{-1} 7$. [Changes in oxygen isotope composition are said to correspond with the extraction of large amounts of water from the oceans during glacial periods and the recirculation of this water during periods when glaciers were at their present levels.]

Shotron, F. W. Age of the Irish Sea glaciation of the Midlands. Nature, Vol. 215, No. 5108, 1967, p. 1366. [Letter. Ice advance in central England dated as late Würm.]

Shotтon, F. W. The problems and contributions of methods of absolute dating within the Pleistocene period. Quarterly Journal of the Geological Society of London, Vol. 122, No. 488, Pt. 4, 1966, [pub.] 1967, p. 357-83. [Radiocarbon dates now indicate that the Würm glaciation in the northern hemisphere had two stadia of approximately equal importance.]

Souchez, R. A. Le recul des verrous-gradins et les rapports glaciaire-périglaciaire en Antarctique. Revue de Géomorphologie Dynamique, An. 17, No. 2, I967, p. 49-54. [Study of glacial erosion by outlet glaciers in south Victoria Land and in western Sør-Rondane mountains, Dronning Maud Land. Relation between periglacial processes and glacial erosion.] 
Souchez, R. A. Réflexions sur l'évolution des versants sous climat froid. Revue de Géographie Physique et de Géologie Dynamique, Sér. 2, Vol. 8, Fasc. 4, 1966, p. 31 7-34. [Discussion of evolution of slopes in a cold climate.]

Souchez, R. A. Sur les mécanismes de l'érosion en Antarctique. Bulletin de la Société Belge d'Études Géographiques, Tom. 35, No. I, 1966, p. 25-34. [Stresses idea of glacial erosion under ice falls of distributary glaciers.]

Szupryczý́ski, J. Przebieg deglacjacji na obszarze pólnocnego Spitsbergenu w rejonie fiordu Bock. Przegląd Geograficzny, Tom 38, Zeszyt 3, 1966, p. 407-28. [The course of deglaciation in north Vestspitsbergen in the Bock Fjord region. Extended summaries in Russian and English.]

\section{Frost action on rocks and soll. Frozen ground. Permafrost}

Anderson, D. W., and others. Frost phenomena on Mars, by D. W. Anderson, E. S. Gaffney and P. F. Low. Science, Vol. 155, No. 376o, 1967, p. 319-22. [Suggests frost phenomena are not to be expected on Mars without strongly deliquescent soils.]

Baulin, V. V. Moshchnost' merzlykh tolshch kak odin iz pokazateley tektonicheskogo stroyeniya rayona [Thickness of the frozen layer as an indicator of the tectonic structure of a region]. Geologiya $i$ Geofizika [Geology and Geophysics], 1966, No. I, p. 53-62. [Correlation between permafrost thickness and tectonic movement in west Siberian plain. English translation: Canada. Defence Research Board. Translation T464R, 1966.]

BLACK, R. F. Ice-wedge casts of Wisconsin. Transactions of the Wisconsin Academy of Sciences, Arts and Letters, Vol. 54, 1965 , p. $187-222$. [Description of these features and their locations, discussion of mode and time of formation and their palaeoclimatological significance.]

Black, R. F., and Bowser, C. J. Patterned ground studies in Victoria Land. Antarctic Fournal of the U.S., Vol. 2 , No. 4 , 1967, p. $116-18$. [Studies to define the environment of sand and ice wedges and to determine their rate of growth for dating of various surfaces.]

Brown, R. J. E. Comparison of permafrost conditions in Canada and the USSR. Polar Record, Vol. I3, No. 87 , I 967 , p. $74 \mathrm{I}-5 \mathrm{I}$. [Despite the disparity in knowledge of permafrost conditions in the two countries, it is clear that significant differences do exist.]

Cailleux, A. Actions du vent et du froid entre le Yukon et Anchorage, Alaska. Geografiska Annaler, Vol. 49A, Nos. $2-4$, I967, p. 145-54. [Observations on the influence of wind and frost action, made during the INQUA field trip in Alaska in 1965 , reported, discussed and compared with examples from other areas.]

Chambers, M. J. G. Investigations of patterned ground at Signy Island, South Orkney Islands. III. Miniature patterns, frost heaving and general conclusions. British Antarctic Survey Bulletin, No. 1 2, 1967, p. 1-22. [Experiments on development of these features.]

Couvreur, G. Les formations périglaciaires du Haut Atlas central marocain. Revue de Géographie de Maroc, No. Io, r 666 , p. 47-50. [Quaternary and present periglacial processes described. Importance of aspect and nature of rocks.]

DAHL, R. Block fields and other weathering forms in the Narvik mountains. Geografiska Annaler, Vol. 48A, No. 4, I966, p. 224-27. [Reply to criticism by Ives, ibid., Vol. 48A, No. 4, p. 220-23.]

Danilova, N. S. Obrazovaniye tonkikh ledyanykh zhil i psevdomorfoz no nim v peschanom allyuvii del'ty $\mathrm{r}$. Leny [The formation of thin ice veins and the pseudomorphism by them in sandy alluvium of the Lena delta]. Vestnik Moskovskogo Universiteta. Seriya 5 [Messenger of Moscow University. Series 5], God 21, [No.] 6, I966, p. 108-I I.

Dikinov, $\mathrm{K}_{\mathrm{H}}$. $\mathrm{Z}_{\mathrm{H}}$. Raschet glubiny promerzaniya pochvy, pokrytoy snegom, po zadannoy temperature vozdukha [The calculation of the freezing depth of the soil covered by snow at a given air temperature]. Izvestiya Akademii Nauk SSSR. Fizika Atmosfery i Okeana [News of the Academy of Sciences of the U.S.S.R. Physics of the Atmosphere and Ocean], Tom 3, No.6, 1967, p. 602-10. [Numerical solution of equations. Results compared with observations. English summary.]

Dylik, J. Solifluxion, congelifluxion and related slope processes. Geografiska Annaler, Vol. 49A, Nos. 2-4, 1967, p. $167-77$.

DyLik, J. Traces fossiles de l'évolution descendante des polygones des fentes de gel. Tijdschrift van het koninklijk Nederlandsch Aardrijkskundig Genootschap, Deel 83, No. 3, 1966, p. 227-37. [Discussion of what can be learnt by studying fossil frost-wedge polygons.]

Everetr, K. R. Mass-wasting in the Tasersiaq area, West Greenland. Meddelelser om Grenland, Bd. I65, Nr. 5 , $1967,31 \mathrm{p}$. [Description of geology and geomorphology of this area marginal to Sukkertoppen Iskappe with special emphasis on mass-wasting processes including solifluction and slumping.]

[Frozen ground: Canada.] Permafrost in Canada. Canada. Geological Survey. Dept. of Energy, Mines and Resources. Map I246A, 1967. [Scale I : 7603 200.] 50 c. [Shows extent of continuous and discontinuous permafrost zones and occurrence of permafrost at high elevations, with other data. Explanatory notes on definition of permafrost, distribution and occurrence, physical factors influencing permafrost and a bibliography of source information are printed on the map.]

Gabert-Delay, J. L'importance des déformations quaternaires et du modelé cryonival würmien dans les paysages du bas Rhône et de la basse Durance. Méditerranée. Revue Géographique des Pays Méditerranéens, $8 \mathrm{e}$ An., No. 2, ${ }^{1967}$, p. 87-107. [Importance of Quaternary deformations and periglacial processes in the Würm period in landform development of this region of southern France.]

Hoenstra, P. Conductance of frozen bentonite suspensions. Proceedings. Soil Science Society of America, Vol. 29, No. 5,1965 , p. $5^{19-22}$. [Evidence for films of unfrozen water on clay particles in frozen soil.]

Holdgate, M. W., and others. A preliminary investigation of the soils of Signy Island, South Orkney Islands, by M. W. Holdgate, S. E. Allen and M. J. G. Chambers. British Antarctic Survey Bulletin, No. 12, 1967 , p. $53^{-71}$. [Mechanical break-down of rock by frost action is proceeding rapidly and solifluction processes are influencing the upper layers of the ground on a large scale.] 
Ives, J. D. Block fields, associated weathering forms on mountain tops and the nunatak hypothesis. Geografiska Annaler, Vol. 48A, No. 4, 1966, p. 220-23. [Criticism of paper by Dahl, ibid., Vol. 48A, No. 2, 1966, p. 55-85.]

Juusela, T. Some results of field observations on the frost phenomenon on peat soil. Fournal of Hydrology (Amsterdam), Vol. 5, No. 3, 1967 , p. 269-78. [Measurement of frost depth and moisture content throughout the winter.]

KLyUyev, Ye. V. Proyavleniye termokarsta na dne morya Laptevykh [Appearance of thermokarst on the floor of the Laptev Sea]. Problemy Arktiki $i$ Antarktiki [Problems of the Arctic and Antarctic], Vyp. 23, 1966, p. 26-32.

Lewin, J. Fossil ice wedges in Hampshire. Nature, Vol. 2 I I, No. 5050, 1966, p. 728. [Description of forms and suggested date.]

LiestøL, O. Lokalt område med permafrost i Gudbrandsdalen. Norsk Polarinstitutt. Arbok, 1965 [pub. I966], p. 129-33. [Small local permafrost area discovered near Otta in Gudbrandsdalen, central Norway, in 1965 . English summary.]

McCraw, J. D. Some surface features of McMurdo Sound region, Victoria Land, Antarctica. New Zealand Fournal of Geology and Geophysics, Vol. 10, No. 2, 1967, p. 394-41 7. [Description of rock weathering, debris movement, glacial and fluvioglacial deposits, and patterned ground.]

Mackay, J. R. Permafrost depths, lower Mackenzie Valley, Northwest Territories. Arctic, Vol. 20, No. I, I967, p. $21-26$. [Measurements at 7 new sites and discussion.]

McManus, J. An ice-wedge and associated phenomena in the Lower Limestone series of Fife. Scottish Journal of Geology, Vol. 2, No. 3, 1966, p. 259-64. [Description of fossil ice wedge.]

Rougerie, M. G. Filiation de sols figurés au Spitzberg nord-occidental. Bulletin de l'Association de Géographes Français, No. 346-47, i 966, p. 32-40. [Study of possible relationship between different forms of frost action on superficial deposits at Kvadehuken, Vestspitsbergen.]

Shmelev, L. M. Proiskhozhdeniye plastovykh zalezhey podzemnogo l'da v nizov'yakh r. Yeniseya [Origin of the bedded deposits of underground ice (the lower Yenisey)]. Izvestiya Akademii Nauk SSSR. Seriya Geograficheskaya [News of the Academy of Sciences of the U.S.S.R. Geographical Series], 1967, No. 2, p. 108-15.

Tedrow, J. C. F. Polar desert soils. Proceedings. Soil Science Society of America, Vol. 30, No. 3, 1966, p. $381-87$. [Review of physical conditions in high Arctic, resulting soils and patterned ground.]

Tedrow, J. C. F., and Ugolini, F. C. Antarctic soils. (In Tedrow, J. C. F., ed. Antarctic soils and soil forming processes. Washington, D.C., American Geophysical Union, 1966, p. 161-77. (Antarctic Research Series, Vol. 8.)) [Description of weathering processes and resulting soil types.]

Tolstiknin, O. N. Pritok vody ot naledey v basseyne r. Indigirki [Flow of water from "icings" in the Indigirka basin]. Meteorologiya i Gidrologiya [Meteorology and Hydrology], i966, No. 9, p. 1 7-22. [Observations of volume of run-off from giant ice-mounds.]

Williams, P. J. Downslope soil movement at a sub-arctic location with regard to variations with depth. Canadian Geotechnical fournal, Vol. 3, No. 4, 1966, p. 191-203. [Soil movements resulting from solifluction were investigated at Schefferville, P.Q., variation of movement with depth below surface being specially considered.]

\section{Meteorological and GLimatological glaciology}

Browning, K. A. Hailstones breaking in mid-air. Weather, Vol. 22, No. 8, 1967, p. 331-34. [A small but significant proportion of hailstones may break up in mid-air by natural causes.]

Hitschfeld, W., and Stauder, M. The temperature of hailstones. Fournal of the Atmospheric Sciences, Vol. 24, No. 3,1967 , p. 293-97. [Theoretical study shows hailstones $10 \mathrm{~mm}$ in radius may be $c$. $12 \mathrm{deg}$ colder than surrounding air.]

Knollenberg, R. G. Urea as an ice nucleant for supercooled clouds. Fournal of the Atmospheric Sciences, Vol. 23, No. 2, 1966, p. 197-201. [Laboratory and field tests.]

Kupetskiy, V. N. O prichinakh teplovoy asimmetrii Antarktiki [The reasons for the thermal asymmetry of the Antarctic]. Izvestiya Vsesoyuznogo Geograficheskogo Obshchestva [News of the All-Union Geographical Society], Tom 98, Vyp. 2, 1966 , p. 130-37. [Discusses cause of asymmetry of Antarctic ice sheet and surrounding oceans.]

SAnsom, H. W. A possible effect of lightning on hail. Weather, Vol. 21, No. 9, 1966, p. 315. [Evidence for hailstone softening by shock wave from lightning flash.]

Starr, J. R., and MAson, B. J. The capture of airborne particles by water drops and simulated snow crystals. Quarterly Journal of the Royal Meteorological Society, Vol. 92, No. 394, 1966, p. 490-99. [Experiments with paper models of snow crystals on capture of pollen grains.]

Weyant, W. S. The Antarctic climate. (In Tedrow, J. C. F., ed. Antarctic soils and soil forming processes. Washington, D.C., American Geophysical Union, 1966, p. 47-59. (Antarctic Research Series, Vol. 8.)) [General description of three broad climatic zones.]

Whitehurst, C. A. A survey of research efforts in heat transfer through frost formation. ASHRAE Journal (New York), Vol. 8, No. 10, 1966, p. 50-55. [Survey of abstracts and paraphrases. Recommendations for future research.]

\section{SNow}

Isono, K., and others. A physical study of solid precipitation from convective clouds over the sea: part I, by K. Isono, M. Komabayashi and T. Takahashi. Journal of the Meteorological Society of Japan, Ser. 2, Vol. 44, No. 3, 1966, p. 178-84. [Deuterium content of snow crystals with respect to crystal shapes and their relation to origins of the water vapour of snowfall.]

Isono, K., and others. A physical study of solid precipitation from convective clouds over the sea: part II, by K. Isono, M. Komabayashi, T. Takahashi and T. Tanaka. Journal of the Meteorological Society of Japan, Ser. 2, Vol. 44, No. 4, 1966, p. 218-26. [Relation between ice nucleus concentration and precipitation.] 
Isono, K., and others. A physical study of solid precipitation from convective clouds over the sea: part III, by K. Isono, M. Komabayashi [and] T. Takahashi. Journal of the Meteorological Society of Japan, Ser. 2, Vol. 44, No. 4, I966, p. 227-33. [Measurement of electric charge of snow crystals.]

Isono, K., and others. A physical study of solid precipitation from convective clouds over the sea: part IV, by K. Isono, M. Komabayashi, T. Takahashi and T. Gonda. Journal of the Meteorological Society of Japan, Ser. 2 , Vol. 44, No. 6, r 966, p. 308-ig. [Importance of giant sea salt nuclei in formation of solid precipitation.]

KAISERgRUBER, F. Eine merkwürdige Schneeform ("Schneerollen"). Wetter und Leben, Bd. 1 7, Ht. 3-4, 1965, p. 67-68. [Description of curious toroidal form.]

MagONo, C., and KIKUCHI, K. On the positive electrification of snow crystals in the process of their melting (II). Journal of the Meteorological Society of Japan, Ser. 2, Vol. 43, No. 6, 1966, p. 331-42. [Measurement of charge on snow crystals in process of melting.]

Magono, C., and Nakamura, T. Aerodynamic studies of falling snowflakes. Fournal of the Meteorological Society of Japan, Ser. ${ }^{2}$, Vol. 43, No. 3 , 1965, p. $139-47$. [Simultaneous observations of fall velocity, size and mass.]

Martinelli, M., jr. Avalanche technology and research: recent accomplishments and future prospects. Weatherwise, Vol. I9, No. 6, I966, p. 270-71. [Including current avalanche control and forecasting techniques.]

Ōura, H., and Kobayashi, D. Sekisetsu no ryūdo bumpu no motomekata ni tsuite [On the method of size frequency distribution analysis of ice particles in snow cover]. Teion-kagaku [Low Temperature Science], Ser. A, Vol. 24, I 966, p. I39-57. [Determination from microphotographs of cross-sections of snow cover. English extended summary p. 155-57.]

Pitman, D., and Zuckerman, B. Effective thermal conductivity of snow at $-88^{\circ},-27^{\circ}$, and $-5^{\circ} \mathrm{C}$. 7 ournal of Applied Physics, Vol. 38, No. 6, I967, p. 2698-99. [Measurements of conductivity of "snow" made from dendritic frost crystals with density from 0.1 to $0.6 \mathrm{~g} \mathrm{~cm}^{-3}$. Comparison with previous work and theory.]

RAкiтA, S. A. Vliyaniye rastitel'nosti na perenos i otlozheniye snega v gorakh basseyna Kolymy [Influence of vegetation on transport and deposition of snow in the mountains of the Kolyma basin]. Vestnik Moskovskogo Universiteta. Seriya 5 [Messenger of Moscow University. Series 5], God 21, [No.] 3, 1966, p. 103-07.

Roch, A., and Fraser, C. How to estimate avalanche danger. Alpine Journal, Vol. 72, No. 314, r967, p. 87-94.

Stow, C. D. The generation of electricity by blowing snow. Weather, Vol. 23, No. 9, 1967, p. 371-77. [Three types of interaction, all involving the temperature-gradient effect, are primarily responsible for the observed electrification.]

Тном, H. C. S. Distribution of maximum annual water equivalent of snow on the ground. Monthly Weather Review, Vol. 94, No. 4, r966, p. 265-71. [Study of statistical distribution.]

TushinskiY, G. K., and others. Karta lavinoopasnykh rayonov SSSR [Map of avalanche-dangerous regions in the U.S.S.R.], [by] G. K. Tushinskiy, K. V. Akif'yeva, N. A. Volodicheva, N. L. Kondakova, G. S. Konstantinova, V. I. Kravtsova, I. S. Kuz'mina, V. F. Perov, S. A. Rakita, Ye. S. Troshkina, O. A. Shleynite. Vestnik Moskovskogo Universiteta. Seriya 5 [Messenger of Moscow University. Series 5], God 22, [No.] I, 1967, p. 3-14.

Wilken, G. C. Snow accumulation in a manzanita brush field. Water Resources Research, Vol. 3, No. 2, ig67, p. 409-22. [Study of how snow accumulates in areas of Sierra Nevada, U.S.A., covered by this shrub.]

Zanin, G. V. Snezhnye melioratsii i geomorfologicheskiye protsessy [Snow irrigation and geomorphological processes]. Izvestiya Akademii Nauk SSSR. Seriya Geograficheskaya [News of the Academy of Sciences of the U.S.S.R. Geographical Series], 1966, No. 3, p. 49-51.

\section{ERRATUM (Vol. 6, No. 45)}

In the entry in "Glaciological literature" on p. 473, Woldstedt, P. Die interglazialen . . ., the note in square brackets should read: [The interglacial marine beaches are "raised beaches" and do not prove a former higher ocean level; it can be shown that ocean levels have not altered appreciably during the Quaternary, thus most Antarctic ice must have been formed before this.]

\section{NOTE FOR AUTHORS}

In view of the impending retirement of Dr. Gerald Seligman from his Editorship of the Journal of Glaciology, authors are requested to send their manuscripts to Dr. J. W. Glen, Department of Physics, University of Birmingham, P.O. Box $36_{3}$, Birmingham 15, England and not to Dr. Seligman. 